\title{
DIALEKTIKA MANUSIA DAN AGAMA
}

\author{
Oleb : Mub. Yunus
}

\section{Wacana Pengantar}

Memperhatikan wacana pemikiran agama (Islam) komtemporer, eksistensi "agama" sering mendapat "gugatan". Sebut saja di Timur Tengah misalnya, mucul cendekjawan muslim semacam Hasan Hanafi denagn konsp Islam kirinya -al Yasar al Islam- (Simogaki : 1989), Thoha Husein denagn pemikiran sekularisasinya (Husein : 1998), An-Na'im dengan Dekonstruksi Syari'abnya (An-Na'im : 1998), Ali Syari'ati melalui essay-essay kritisnya tentang masyarakat muslim (Syari'ati : 1982), dan masih banyak lagi.

Sementara di Indonesia bisa disebut misalnya, Nurcholish Madjid yang konsisten memperkenalkan konsep kalimatun Sawa' (titik persamaan) agamaagama samawi dalam Islam, Doktrin dan peradapan (Paradima : 1992). Demikian pula M.Amin Abdullah yang berusaha melihat keberagaman manusia dari sudut historis (Abdullah : 1999) keluar dari kungkungan paradigma normatifnya. Sedang dilingkungan IAIN-STAIN di Indonesia sejak tahun 1997 (Mudzhar : 1999) telah digalakkan studi Islam dengan penekanan pada metodologinya, bukan isi materinya sebagaimana pada mata kuliah yang diajarkan sebelumnya, Dirosab Islamiyab. Dan satu lagi yang masih aktual, Dekonstruksi Islam oleh orang-orang Ciputat dengan mendirikan Madzhab Ciputat (Efendy, : 1999).

Pendek kata, agama sering mendapat auto critique dari para pendukungnya sendiri. Tokoh-tokoh muslim lain semacam K.H. Abdurrahman Wahid (Gus Dur), M.Amin Rais, dan cendekiawan muda semisal Masdar Farid Mas'udi, Muslim Abdurrahman dan kawan-kawannya -tak ketinggalan juga kawan-kawan yang tergabung dalam Lembaga Studi dan Pengembangan Umat (LSPU) GNOSIS Malang adalah sebagian diantara sederetan tokoh yang sering mempertanyakan peran agama bagi masyarakatnya.
Mempertanyakan tentu untuk menyegarkan pemahaman keagamaan para pemeluknya. Hal ini bukan berarti para penganutnya mulai meninggalkan agama, tetapi justru melalui kritik itulah mereka berusaha memperdalam tentang agama mereka, -kritik adalah solusi-.

\section{Kenapa Agama (Islami) digugat ?}

Secara umum, semua agama (termasuk Islam) sekurang-kurangnya menurut. Bambang Sugiarto (Andito : 1998) menghadapi tiga tantangan berat. Pertama, dalam menghadapi persoalan kontemporer yang ditandai disorientasi nilai dan degradasi moralitas, agama ditantang untuk lebih tampil sebagai suara moral yang otentik. repotnya, agama-agama yang ada masih teramat disibukkan oleh krisis identitas dalam dirinya sendiri, yang sering menjebak mereka ke dalam pertengkaran yang remeh-remeh; kedua, siap tidak siap agama juga harus mampu menghadapi kecenderungan pluralisme, mengolahnya dalam kerangka teologi baru dan mewujudkannya dalam aksi-aksi kerja sama plural. Ketiga, bila agama ingin berperan penting dalam situasi kemelut pos modern ini ia mesti tampil, dengan cara apapun, sebagaipelopor perlawanan terhadap segala bentuk penindasan dan ketidak adilan, termasuk "ketidak adilan kognitif" yang biasanya diciptakan antara lain justru oleh agama-agama itu sendiri. Inipun memerlukan pengkajian ulang kerangka-kerangka teologis baku.

Dari tiga tantangan tersebut, tampak jelas bahwa eksistensi dan peran agama (Islam) mendapatkan kririk tajam, yang intinya perlu adanya pengkajian ulang terhadap dogma agama yang selama ini telah membeku, jika agama tidak ingin ditinggalkan begitu saja oleh derasnya arus modernisasi. Dari sini muncul pertanyaan : sebenarnya agama itu untuk siapa? Sesungguhnya agama itu diturunkan Tuhan ke bumi 
memang untuk manusia. Jacli agama lahir untuk manusia, bukan manusia lahir untuk agama (baca : Tuhan). Jika manusia lahir untuk agama, maka yang paling menonjol adalah dimensi transenden-nya, dunia agama tempat asal ia turun, jauh dari bumi. jika demikian, maka manusia masuk kedalam dunia alkoboloistik-teosentris, mabuk ketuhanan. Tetapi sebaliknya, jika diturunkanya agama untuk manusia, maka agama itu bersifat sangat antropologis. Hal yang demikian ini bukan berarti manusia beragama hanya untuk kebahagiaan di clunia saja, tetapi kabahagiaan di clunia yang didalamnya sarat muatan spiritualitas clan moralitas, clan semua itu kembali lagi untuk manusia di bumi. Argumentasi bahwa agama itu diturunkan untuk manusia, adalah relevan dengan pernyataan Tuhan sendiri, bahwa keagungan dan kekuasaan Tuhan tidak akan bertambah atau berkurang walaupun seluruh penducluk bumi ini menyembah kepadaNya atau ticlak.

Sebagai bukti bahwa agama itu banyak pro pada persoalan kemanusiaan, Jalaluddin Rachmat telah melakukan penelitian untuk itu.

Dari tiga tantangan tersebut, tampak jelas
bahwa eksistensi dan peran agama (Islam)
mendapatkan kririk tajam, yang intinya perlu
adanya pengkajian ulang terhadap dogma
agama yang selama ini telah membeku, jika
agamatidakinginditinggalkan begitu saja oleh
derasnya arus modernisasi. Darl sini muncul
pertanyaan : sebenarnya agama itu untuk
siapa? Sesungguhnya agama itu diturunkan
Tuhan ke bumi memang untuk manusia. Jadi
agama lahir untuk manusia, bukan manusia
lahir untuk agama (baca : Tuhan). Jika
manusia lahir untuk agama, maka yang pal-
ing menonjol adalah dimensi transenden nya,
dunia agama tempat asal la turun, jauh dari
bumi.jika demikian, maka manusia masuk
kedalam dunia alkoholoistik-teosentris,
mabu kketuhanañ.

Dari tiga tantangan tersebut, tampak jelas bahwa eksistensi dan peran agama (Islam) mendapatkan kririk tajam, yang intinya perlu adanya pengkajian ulang terhadap dogma a agama lidakingin dilinggalkan begitu saja oleh pertanyaan : sebenarnya agama itu untuk siapa? Sesungguhnya agama itu diturunkan Tuhan ke bumi memang untuk manusia. Jadi agama lahir untuk manusia, bukan manusia ahir untuk agama (baca : Tuhan). Jika manusla lahir untuk agama, maka yang paldunia agama tempat asal ta turun, jauh dari buml. jika demikian, maka manusia masuk mabukketutianan la menyimpulkan bahwa di dalam Al-Qur'an terclapat empat hal yang bertemakan kepeduliannya terhadap masalah sosial kemanusian. Pertama, clalam Al-Qur'an kitab-kitab Hadits, proporsi terbesar ditujukan pada urusan sosial. kedua, dalam kenyataan bila masalah mu'ammalah yang penting, maka ibaclah boleh diperpedek atau ditangguhkan. ketiga, bahwa ibadah yang mengandung segi kemasyarakatan diberi pahala besar dari pada ibadah yang bersifat perseorangan. keempat, bila persoalan iabclah dilakukan tidak sempurna atau batal, karena melanggar pantangan tertentu, maka kafarat-nyà (tebusannya) ialah melakukan sesuatu yang berhubungan clengan masalah sosial (jalaludin Rachmat calam Abuddin nata : 1999).

bersarkan kajian di atas menunjukkan bahwa Islam adalah agama kemanusiaan. karena itu tepat jika Prof. Fazlur Rachman mengatakan bahwa Al-Qur'an bukan buku ketuhanan, apalagi buku hukum, melainkan buku petunjuk bagi manusia (Abdullah : 1999). Bahkan lebih tegas ia sampai pada suatutesis bahwa secara eksplisit dasar ajaran Al-Qur'an aclalah moral yang memancarkan titik eratnya pada monoteisme dan keadilan sosial (rahman dalam nata : 1999). manifestasi dari ajaran monoteisme (tawbid), clan keadilan sosial ini clapat dilihatpada doktrin tentang ibaclah yag sarat denagn muatan iman clan taqwa yang harus clirealisasikan clalam bentuk akhlak mulia. Denagn demikian yang climaksud dengan mu'min, muslim, dan muttagin sebenarnya adalah orang yang bermoral tinggi clan berbucli pekerti luhur (Nasution : 1985).

Permasalahannya adalah : kenapa grand message atau major themes of Qoran yang sedemikian memperhatikan aspek bumanisme itu clalam clataran empiriknya jauh clari pesan-pesan ideal Al-Qur'an? Adakah agama suclah berkurang untuk tidak mengatakan tidak ada- claya tariknya? ataukah manusianya yang salah dalam mamaknai pesan-pesan Tuhan yang disimbolkan dalam ritus-ritus, peribadatan-peribadatan, atau institusi agama dan keagamaan? ataukah mungkin karena perubahan masyarakat menjelang milenium III yang luar biasa cepat ini, sehingga agama sudah tidak relevan dan ketinggalan kereta dalam mengantisipasi perubahan 
jaman? pertanyaan-pertanyaan tersebut jika dikembangkan akan melahirkan sederetan masalah yang panjang, yang pada akhirnya bumi ini hanya penuh sesak dengan pertanyaan-pertanyaan. Itulah sebenarnya yang penulis maksudkan dengan "agama" di gugat oleh manusia, mahluk yang sebenarnya justru diberi tuntunan hidup oleh agama demi kebahagiaan manusia sendiri. menggugat "agama" pada dasarnya juga menggugat manusianya sebagai pihak yang berhubungan dengan agama, penafsir dan dan penerima agama. Disinilah mendiskursuskan manusia dan agma menjadi menarik sepanjang sejarah umat manusia. Sebab jika Sejarab umat manusia beragama itu dilepaskan dari masyarakatnya, dunia yang kosong tanpa sejarah dan peradapan. .

Untuk membatasi permasalahan di atas, dalam tulisan ini hanya akan membahas petanyaan pertama : kenapa Islam sebagai agana kemanusiaan tetapi dalam dataran realitas-empiriknya jauh daripesan idealnya ?

Menurut hemat penulis faktor pertama yang menyebabkan manusia jauh dari pesan ideal Al-Qur'an adalah faktor pemahaman terhadap agama: Serangkaian ibadah yang dilakukan umat beragaina (Islam) seperti shalat, zakat, puasa, haji, dan sejenisnya hany a berhenti pada sebatas menjalankan kewajiban (figh orie nted) dan menjadi simbol kesalehan, sedangkan buah ibadah yang berdiensi sosial kưrang nampak. Dikalangan masyarakat beragama, telah terjadi kesalah. pahaman dalam memaknai dan. menghayati serta mengapresiasi pesan simbolik itu. Akibatnya, agama hanya di pahami sebagai penyelamat indivídu dan bukan sebagai keberkahan sosial
Dataran empirik itu dapat kita saksikan pada lembaranlembaran hitam serangkaian lukisan nasib rakyat kecil yang jarang disapa oleh kaum borju dan ellite, mereka yang memposisikan dirinya sebagai manusia modern. Demikian pula sederetan peristiwa menyedihkan seperti kerusuhan, bentrokan antar pendukung partai yang berbasiskan masyarakat beragama, dan gambaran peristiwa-peristiwa lain yang menyedihkan umat, menenggelamkan manusia pada endapan lumpur yang kotor.

Problem Manusia Modern dan Pergeseran Paradigma pemahaman Agama
Dikalangan nlasyarakat beragama, telah tejjadi kesalah pahaman dalam memaknai clan menghayati serta mengapresiasi pesan simbolik itu. Akibatnya, agama hanya di pahami sebagai penyelamat individu dan bukan sebagai keberkahan sosial -anekdotnya, masuk surga kok sendirian, mestinya ya mengajak yang lain untuk sama-sama masuk surga-.

Pemahaman agama yang demikian itu, seolaholah Tuhan tidak hadir dalam problematika sosial kita, kendatiasma-asmaNya sering disebut-sebut kapan dan dimana saja. pesan moral, spiritual, dan keadilanssosial agama menjadi mandeg, terkristal dalam kumpulan mitos dan ungkapan simbolik, kosong tanpa makna. 
Agama tidak muncul dalam suatu kasadaran kritis terhadap situasi sosial (Abdurrahman dalam Nata : 1999). Idiom-idiom Al-Qur'an yang sangat antropologis, seperti Hudan Linnas (Petunjuk bagi seluruh manusia), Syifa'lima fiial sudur (obat bagi penyembuhan penyakit- penyakit yang ada di dada; Q.S. Yunus : 57), kumtum kbaira ummab (sebaikbaik ciptaan), termasuk istilah Khalifab fil ardi wakil Tuhan di bunii) (Abdullah : 1999) hanya berhenti pada ungkapan simbolik tanpa ruh.

Faktor kedua, selama ini umat beragama sering menghabiskan energi untuk menghadapi "musuhmusuh semu" (pseudo-enemis), Sehingga sering terjebak kedalam primodialisme sempit yang sering mengakibatkan timbulnya arnakisme. Musuh sejati umat beragama bukanlah umat yang memeluk agama lain, melainkan tantangan kontemporer berupa kaburnya arah masa depan peradapan, pudarnya nilai-nilai serta segenap perkembangan destruktif lainnya (sofyan, 1999). lebih tegas dikatakan oleh bambang Sugiarto bahwa ; yang danggap "musuh" itu bisal jadi sebenarnya hanyalah simbol-simbol dari kekacauan tanpa bentuk dalam diri mereka sendiri. Ini analog denagn orang yang sedang mengalami tekanan mental hebat tiba-tiba menembaki setiap yang di jumpai (Andito : 1998).

Pesan ideal Tuhan melalui firman-Nya yang tertuang dalam Al-Quran, diturunkan kepacla Nabi SAW lewat perantaraan malaikat Jibril, berisi pedomandasar bagi kehidupan manusia menuju kebahagiaan di dunia dan hidup setelahnya, itulah agama (Islam). Agama yang demikianini di pahami sebagai doktrin (wahyu) yang a-bistoris, telah sempurna dan tidak perlu diotak-atik. Padahal agama juga bisa dipahamisebagai gejala budaya, gejala sosial, wahyu dan produk sejarah (Mudzar : 1999). Agama sebagai gejala budaya, dapat dilihat pada lima komponennya : (1) scripture (naskah-naskah) agama seperti Al-Qur'an dan Al-Hadits serta sumber-sumber hukum Islam lainnya. Bagaimana naskah-naskah agamatersebut berbicara tentang manusia, (2) para pemipin dan penganut agama, kenapa dan bagaimana keduanya mengikuti dan memahami ajaran agama, (3) praktek ritual dan simbol-simbol peribadatannya, motif apa melakukan ritus keagamaan dan bagaimana perilaku ritual tersebut dijalankan, (4) tempat ibadah, masjid misalnya. Kapan, dimana, dan semacamnya. itulah eksistensi agama yang termanifestasikan dalam dataran empirik, agama sebagai gejala budaya.

Sedangkan agama sebagai gejala sosial, nampak dari pergeseran paradigma manusia modern dalam memandang agama. terhadap standar kesalehan beragama misalnya, sebagian besar masyarakat desa masih memandang bahwa orang mu'min itu ya harus pergi shalat jum'at ke masjicl. jika ticlak, maka tidak termasuk orang saleh. Sementara di kota, orang pergi shalat jum'at ke masjid di sekitarnya atau tidak, ia tidak serta merta dianggap tidak saleh. inilah sebagian tanda bahwa agama dipahami sebagai gejala sosial dari bentuk perilaku-perilaku keagamaan pemeluknya. Dan terakhir, agama sebagai wahyu dan produk sejarah. Sebagai wahyu, agama bersifat doktriner, sudah taken for granted, given. Dan agama sebagai produk sejarah, apa yang dihasilkan dari sejak nabi diutus hingga berkembang pada hari ini, tentu telah menghasilkan sejarah panjang baik di bidang hkum, peradapan islam, seni budaya, sain dan teknologi, dan semacamnya. Produk sejarah yang dihasilkan oleh orang-orang muslim itu tidak bisa dilepaskan dari manifestasinya sebagai seorang muslim yang menganut ajaran Tuhan.

Jika produk sejarah itu dianggap sebagai ajaran (doktrin Agama), maka agama akan mandeg, berhenti pada simbol, tidak tertransformasikan. padahal agama 
selain memiliki sisi normatif (doktrin agama yang universal), bersifat a-bistoris, abadi-seperti kasih sayang, kejujuran dan keadilan sosial—; agama juga bersifat antropologis-historis, menyejarah. Sebagai misal, ajaran Islam mengajarkan untuk menutup aurat. Menutup aurat inilah sisi normatifnya, ajarannya bersifat abadi dan universal. Semantara menutup aurat itu clengan memakai jilbab, kerudung atau pakaian model lain tidlaklah menjadi soal, asal menutup aurat. Oarang Islam Timur Tengah pakai jubah dan cadlar, orang Indoneia pakai sarung dan songkok, yang putri pakai kebaya dan jilbab, clan semacamnya tidak menjasi soal. Inilah sebenarnya aspek historisnya, sesuai dengan budlaya lokal yang bisa diterima oleh masyarakatna. Oleh sebab itu, sisi yang berdimensi budaya bersifat historis, selalu berubah clan berkembang. Konsekwensinya,Pemeluk Islam yang sekarang tidak harus memcontoh persis sebagaimana budaya Islam pada masa Nabi, ulama salaf, clan pendahulu-pendahulunya. Tetapi bisa mencitakan sesuatu-yang lebih baik. Ringkasnya, ajaran al-Quran perlu didialogkan dengan masyarakat dan ditransformaikan, sehingga bisa berdimensi sosial, universal, benar-benar menjadi rahmat bagi sekalian alam.

\section{Pandangan Islam Terhadap Manusia Modern}

Masalah manusia aclalah masalah yang terpenting dari semua masalah. Peradaban modern diclasarkan atas humanisme, martabat manusia serta pemujaan manusia. Kalau sebelumnya manusia memuja Tuhan, lalu jatuh secara bertahap bisa mungkin menjadi penyembah al-Kitab, penyembah Nabi, penyembah simbol agama dan akhirnya penyrmbah tokoh. Jika mengikuti aliran positivistik A. Comte ada tiga tahap evolusi agama yang kan clilalui : tahap rligius, tahap metafisika, dan tahap positif (Hendropuspito : 1994); maka ketika nanusia telah menemukan sains dan teknologi, ia akan meninggalkan Tuhannya, clan pada akhirnya akan beralih mengagungkan sains dan teknologi itu. Pendapat ini senad clengan pendlapatpendapat lain yang mendasarkan dirinya kepada filsafat Humanisme Barat yang menyatakan bahwa selama ini agama-agama telah menghancurkan kepribadian manusia. Manusia clipaksa untuk mengorbankan dirinya demi Tuhan. Agama telah memaksanya untuk berhadpan dengan kehendak Tuhan, maka kehendak manusia sendiri menjadi tak berdaya. Agama selalu memaksanya untuk senantiasa menclambakan sesuatu clari Tuhan, dengan sembahyang dan do'a. Karena itulah filsafat humanisme telah menyatakan oposisi terhaclap agama, -yang bertujuan manurut pengekuannya- untuk memulihkan martabat manusia (Syari'ati : 1982).

Untuk memahami bagaimana posisi manusia yang seclemikian itu, maka terlebih dahulu harus mempelejari bagaimana filsafat kejadian manusia menurut pandangan al-Qur'an. Dalam hal ini, Ali Syari'ati sangat cantik menguak bahasa simbolik alQur'an tantang proseskejadian Adam. Intisari pikiran cendikiawan Iran tersebut sebagaimana tertutur berikut ini.

Dalam pandangan Islam, eksistensi manusia disimbolkan dengan kisah kejadian Adam, yakni kisah kejadian manusia, yang disampaikan secara simbolis. Bermula Allah berfirman kepada para malaikat : "Aku hendak menciptakan khalifah di bumi". Kalau diperhatikan, alangkah luhurnya nilai manusia menurut Islam. Manusia tidak hanya dipaksa jadi obyek, tetapi sebagai subyek, yakni wakil Allah di bumi. Allah memperkenalkanya kepada para malaikatNya. Kemudian berkatalah para malaikat : "Apakah Engkau, ya Allah, hnclak mnciptakan manusia yag akan senantiasa saling menumpahkan darah, berbuat jahat, saling membenci, dan pembalas dendam ?" (karena sebelum Adam sudah ada manusia lain yang, sebagaimana manusia hari ini, selalu saling membunuh, berbuat jahat, korup dan dosa, dan para malaikat ingin mengingatkan Allah bahwa bila Allah hendak menciptakan manusia dan memeberinya lagi kesempatan di bumi, maka manusia kembali akan terlibat dalam baku-hantam dan dosa). Tetapi Allah menjawab, "Aku mengetahui apa yang tidak kalian ticlak ketahui", Lalu diciptakanlah manusia. 
Dalam al-Qur'an disebutkan, ada tiga tempat bahan asal manusia. Mula-mula mempergunakan ungkapan "lempung tembikar" (Q.S. 55 : 14); yakni lempung endapan yang kering. Lalu al-Qur'an menyebutkan, "Kuciptakan manusia dari lempung berbau" (Q.S. 15 : 26), yakni lempung busuk,; kemudian dipergunakan kata tin, juga berarti lempung (Q.S. $6: 2 ; 23$ : 12). Demikianlah Allah menghendaki menciptakan khalifah-Nya; khalifah yang mulia ini dibentuknya dari lempung kering, lalu dihembuskanlah roh-Nya kedalamnya, maka manusiapun jadilah.

Dalam bahasa manusia, lumpur adalah lambang kenistalan yang terendah. Tidak ada makhluk yang 'lebih rendah dari pada lumpur. Sedang zat yang paling luhur paling suci ialah llah, dan bagian terluhur, tersuci dan termulia dari setiap zat ialah roh-Nya. Manusia wakil Allah, diciptakan dari lumpur, clari lempung endapan, dari bahan terendah di dunia, lalu Allah menghembuskan kedalamnya bukan darah-Nya, raga-Nya ataupun semacam it, melainkan roh-Nya, yakni sebutan untuk bagian yang paling erhormat yang terdapat dalam perbendaharaan bahasa manusia. Allah adalah zat termulia, dan roh-Nya adalah suatu konsep terluhur sepanjang akal fikiran manusia.

Jadi manusia adalah gabungan lumpur dan roh Allah. Ia adalah zat yang bidimensional, makhluk yang bersifat ganda, berbeda dengan makhluk-makhluk lain yang undimensional. Dimensinya yang satu cenderung kepada lumpur dan kerndahan, stagnasi dan immobilitas. Sungai mengalir meninggalkan endapan lumpur yang tanpa gerak dan kehidupan. Persis begitu pula sifat manusia, pada satu dimensinya ia cenderung untuk tepaku pada kebisuan beku. Tetapi dimensinya yang lain, yang berasal clari roh Allah. Sebagaimana al-Qur'an menyebutkannya, cenderung untuk meningkat ke puncak yang setinggi-tingginyayakni kepada Allah dan roh Allah.

Demikianlah manusia tediri dari clua anasir yang saling bertentangan, ialah lumpur dan roh Allah; kemuliaan dan keistimewaannya justru karena sifatnya yang bidimensional. Jarak antara kedua dimensinya adalah jarak antara lumpur dan roh Allah. Setiap manusia dikariniai dengan kedua dimensi ini terserah apa kehendaknya; apakah ia akan terperosok ke clalam kutub lumpur endapan yang terdapat dalam dirinya, ataukah ia akan meningkat kearah kutub mulia, yakni ke arah Allah dan roh Allah. Terjadilah pertarungan terus menerus dalam cliri manusia, yang baru akan berakhir bila ia telah memantapkan pilihannya pacla salah satu kutub itu sebagai determinan hidupnya.

Setelah manciptakan manusia, Allah mengajarkan nama-nam kepadanya. Ini merupakan salah satu ayat yang menyatakan bahowa pengajaran adalah pusat perhatian Islam. Setelah itu jadilah manusia sebagai pemilik nama-nam itu. Para malaikat diperintahkan bersujud kepadnya. Inilah humanisme sejati. Betapa agungnya manusia, sampai-sampai para malaikat,makhluk yang lebih baik bahan baku ciptalanya, disurh sujud kepadanya. Manusia unggul karena ilmu pengetahuan yang dimilikina, bukan karena keturunan.

Dari uarian diatas, clapat disimpulkan bahowa : pertam, semua manusi sama dan bersaudara. Kesamaan adalah konsep legal, sedangkan persaudaraan memancarkan kesergaman sifat serta disposisi semua manusia; bagaimanapun keanekaanya, namunmansia berasl dari sumber yang satu. Kedıa, Keunggulan manusia atas para malaikat dan makhluk lainnya berpangkal pacla pengetahuan. Ketiga, kedudukan manusia diantara dua kutub : yakni lumpur dan Allah. Ia memiliki kehendak bebas, bisa bebas memilih satu clari kedua kutub itu : jatuh tersungkur kedalam endapan lumpur, atau naik derajatnya. Karena ia memiliki kehendak bebas, maka ia bertanggung jawab terhadap nasibnya sendiri, disamping itu ia memiliki tugas untuk melaksanakan amanat suci di clunia ini, yakni memakmurkan bumi dan alam sekitarnya (kbalifab fil ardli). Bahwa eksisteni manusia sebagai makhluk bidimensional, ia mampu memberinya daya kekuatan untuk bergerak diantara dua arah yang saling berlawanan di clalam rohani maupun masyarakat manusia. Hanya dengan demikianlah manusia mampu memelihara 
keseimbanganya. Itulah yang ditawarkan oleh agama, Agama Islam.

Ketiga nilai universal : (1) persamaanpersaudaraan, (2) keunggulan manusia atas makhluk lain karena keluasan ilmu pengetahuannya, (3) dan kebebasan manusia sebagaimana disarikan dari diskripsi diatas, adálah hasil kajian deduksi yang ditarik dari al-Qur'an. Bahasa-bahasa simbolik yang ada pada teks dikuliti, dibalik dn dikuak, sehingga makna di balik teks menjadi kelihatan. Dari sinilah lalu bisa ditransformasikan pada kehidupan dunia yang profan, yang sering diwarnai oleh penyakit-penyakit sosial sebagaimana penyimpangan manusia modern yang tergambarkan di atas.

\section{Mencoba Mencari Jalan Keluar}

Sebagai tawaran konsep yang berupa harapan untuk bisa keluar dari kungkungan dunia simbolik dan kehidupan dunia yang penuh masalah ini, pertama, perlu adanya desimbolisasi agama. Nurcholis Madjid dalam era 70-an pernah bikin jargon : Islam Yes, Partai Islam No dan berikutnya John Naisbit yang bilang Spirituality Yes, Organized religion No barangkali masih relevan untuk dihidupkan lagi pada masa akhir-akhir ini. Dengan kata lain, perlu adanyademokratisasi dalam kehidupan agama.

Kedua, Mengembalikan spirit Islam yang sejak awal memiliki semangat liberasi (pembebasan) dan transformasi. Secara simbolik, manusia yang diciptakandari tanah lempung dan ditiupkannya roh Allah serta diberi potensi akal, manusia memiliki kebebasan penuh,tidak ditindas oleh agama. Oleh karena itu, semangat kebebasan ini perlu ditransformasikan clalamkehidupan nyata. Dengan demikian bagi pejuang demokrasi yang menjunjung tinggi martabat manusia tidak perlu lagi mendasarkan dirinya pada filsafat humanisme Barat. Kesalahan arah arah masa depan peradapan bisa diatasi dengan cara mengembalikan semangat bahwa pada dasarnya posisimanusia itu terhormat sebagai kbalifab Allab yang bertugas memakmurkan bmi, bukan membikin kerusikan di bumi. Wallabu A'lam.

\section{BAHAN BACAAN :}

Departemen Agama, Al-Qur'anul Karim dan Terjemabannya. 1995.

Abuddin Nata, Dr., H., Metodologi Studi Islam, PT. Raja Grafindo Persada, Jakarta, 1999.

Ali Syari'ati, On The Sociology of Islam, (terj.), Ananda, Yogyakarta, 1982.

Andito (editor), Alas Nama Agama E Wacana Agama Dlam Dialog "Bebas" Konflik, Pustaka Hidayah, 1998.

D. Hendropuspito, O.C., Drs., Sosiologi Agama, Kasinus-BPK Gunung Mulia, Yogyakarta,1994.

Edy A. Efendy (editor), Dekonstruksi Islam Madzbab Ciputal,Cet.I, Zaman, Bandung, 1999.

Ernest Gellner, Postmodernism, Reason and Religion, terj., Menolak Posmodernisme Antara Fundamentalisme Rasionalis dan Fundamenlalisme Religizls, Hendro Prasetyo dan Nurul Agustina, Mizan, Bandung, 1994.

Harun Nasution, Prof., Dr., Islam Ditinjau dari Berbagai Aspeknya, Jilid I, UI-Press, Jakarta, 1985.

Interfidei, Dialog Kritik E Identitas Agama, Seri Dian I Tahun I.

M. Amin Abdullah, Dr., Studi Agama : Normatifitas atau Historifitas, Pustaka Pelajar, Yogyakarta, 1999.

M. Atho' Mudhar, Dr., H., Pendekatan Siudi Islam Dalam Teori dan Praktek, Pustaka Pelajar, Yogyakarta, 1999.

Muhammad Sofyan, Agama dan Kekerasan dalam Bingkai Reformasi, Media Pressindo, Yogyakarta, 1999.

Kazuo Shimogaki, Belween Medernity and Posmodernity The Islamic Left and Dr. Hasan Hanafi's Thought: A Critical Reading, terj. M. Imam Azis \& M. Jadual Maula, Kiri Islam Antara Modernisme E Posmodernisme Kajian Kritis Alas Pemikiran Hassan Hanafi, LkiS, Yogyakarta, 1993. 